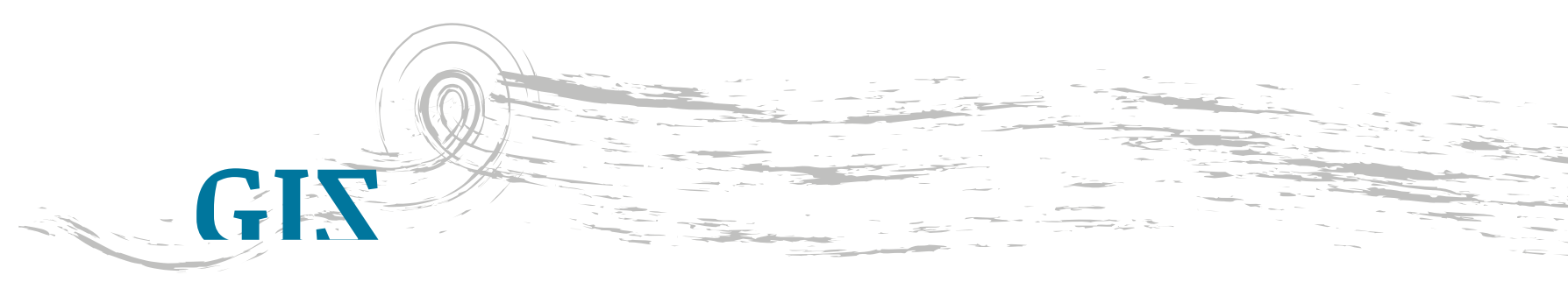

Dol

10.11606/issn.2525-3123. gis. 2021.175885

\title{
DRAWING SIGNS
}

\section{RODERICK PETER STEEL}

ORCID

Universidade de São Paulo, São Paulo, SP, Brasil, 05508-020 eca@usp.br

\section{INNER AND OUTER CIRCLE}

How do ritual and international travel territories work in terms of performativity and embodiment? And when does a journey to either of these places begin and end? Perhaps, more importantly, how do symbols generate energy for these travelling bodies as they negotiate liminal states in these in a parallel and yet disparate universe of the cosmogram and the airport? When air travel started in the 50s some called it a cocktail party on wings: families got dressed up, parents donned their best clothes, and boys knotted ties for the first time. It was like dressing for church, albeit glamorous and jetset. At first glance airports place bodies on a threshold and force travelers to submit to a long line of checkpoints, not entirely devoid of liminality.

In his book "The Life of Lines", Tim Ingold (2015) makes a distinction between the maze and the labyrinth. Within this analogy, the airport is the maze, with corridors demarcated by barriers which obstruct any view other than the way immediately ahead. It channels, diverts and finally confuses the traveler who can easily arrive at the wrong gate, or worse: the wrong terminal. This is a functional, destination-oriented transportation maze. Within Ingold's analysis airports seemingly force travelers to follow pre-defined routes, within a static network of connectors. In Ingold's labyrinth, however, the path is not as clearly delineated,

1 "Drawing Signs" is a performance-lecture in which "photographic-combines", or "polyptic montages" are projected in slideshow show fashion, recalling the days in which anthropologists and other travelers made live presentations of their travels around the world. 
and it is easy to wander off on a tangent, or to "wayfare". Subtler signs indicate the way ahead. States Ingold: "You may sleepwalk or dream along a labyrinth's path, and explore other types of perception, but you must pay attention to the process of walking in order to reach your destination" (Ingold 2015, 131) Does the hand-drawn and ritually-sung cosmogram of the ponto-riscado, which channels multiple moving lines into a central narrative where gods, ancestors, nature and humans become intertwined, encourage such "wayfaring"? And can we really talk about the character of spaces without discussing what happens to the bodies that animate them? Do travelers simply continuously perform pre-assigned roles in an airport, whose often circular design is comparable to a maze (and a mandala) or is the airport more like a ritual cosmogram and the traveler a performer of flights of passage?

Like rituals, air travel is "purposive (devoted to the achievement of a particular objective)," and beyond "ordinary, everyday events" (Tambiah 1981, 113). Air travel resembles a rite: plans begin weeks ahead and generate considerable anticipation in the lead up to what is so often a stressful experience, and involves multiple portals, from choosing a destination to online and on-site check-ins. This rite includes full-body scans - which critics have called "virtual strip searches without probable cause" - and sometimes intrusive physical checks, ase well as close examinations of one's body based on nationality, physical appearance and cultural signifiers. A study that analyzed the perception of airport safety by travelers found that those selected for elevated screenings perceived it as a physical threat and assault on their dignity (Alards-Tomalin et al 2014, 62). Indeed, regular interaction with the triad of gatekeepers - Customs, police and migrations officers - is reminiscent of Foucault's notion of biopower: "mechanisms through which the basic biological features of the human species become the object of a general strategy of power (Foucault 2007, 1)." And the process is repeated when one arrives and then leaves the destination.

The notion of an airport as a liminal space, a site for both affective and emotional intensities, counters Marc Auge's airport as a sterile "non-place", a cultural void, originally coined by the author in the book "Introduction a une antropología de la submodernité." Auge states that places and nonplaces are not real spaces, but imaginary ones, and refers to tourism as an impossible journey. For him, a site passes from the typology of place to non-place whenever it is lacks history and meaning. But can his "Imaginary" in any way be compared to symbolic negotiations of liminal states? Does a traveler pass through what Schechner calls a "period of time when a person is "in between" social categories or personal identities" (Schechner 2012, 63). Do Van Gennep's three rites of passages - separation, liminality, and incorporation - occur in international travel? Does the designation "threshold person" apply the moment a traveler boards a plane? 
When I interviewed High Priest Nilson for the film "Kingdoms"2, he stated that all those arriving at his temple for his Wednesday night "Curing Sessions" must undergo ritual cleansing before participating in the ritual, to rid them of negative "street energies" that had "contaminated" them. The initial posture, for anyone entering a temple, is one of yielding and submission before Exu, the gatekeeper. Stepping into both temple and airport simultaneously deterritorializes and reterritorializes the traveler-visitor. During the pandemic, travelers submit to having temperatures read and taking PCR tests in anticipation of any signs of a potential fever from Covid-19. Similarly, visitors to Pai Nilson's temple line up on a series of long benches against the wall and watch as he enters and praises Indian sprite "Coral Snake", one of the first entities he received in trance when he was fourteen years old and still an umbanda practitioner. He disperses smoke from a Liturgical censer in front of visitors, while chanting song-lines, or pontos-cantados - the lithurgical songs associated with the ponto-riscado - to the Indian spirits. Once he has received Caboclo Sete-Flechas ("Seven-Arrowed Indian") he runs flames from lit candles across his chest, in a series of cross-armed gestures, that mimic the signs on the ponto-riscado. He then redraws these symbols over objects that will be used in the healing session. This cleanses the Indian's medium's - Pai Nilson's - body. He then systematically ritually cleanses and activates other objects with the same gestures, sometimes tracing them in the air. According to the priest:

"What does this ritual do? The entity that possessed me rubs fire over my body, hence purifying the body he is using while reaching out to the initiates' aura and singing, "Run magic Indian! Vanquish opposition and clear the pathways". Once everything has been cleansed it's as if everyone's energy is stabilized and then you begin to cure." (Pai Nilson in an interview for the film "KINGDOMS")

Seven-Arrowed Indian then walks towards the visitors and draws a cross with a large chalk stick (pemba) on each person's forehead, thus embodying one of the founding symbols of the ponto-riscados. Farris Thompson, in "Flash of the Spirit" reminds us that the Yowa cross links the bottom half of the Kongo cosmogram, called Kalunga (the world of the dead is called lunga) with the world of the living on the upper side. In Brazil the cross is multipurpose and demarcates the relationship between deities, entities (or sprites), ancestors, the living and - when applied to candomblé divination - also one's own personal destiny (odu). The Greek cross [ + ] drawn on the ground is the simplest of all ritual spaces. Pai Nilson activates these lines by blowing smoke onto them. "We use smoke to redirect the energies and put them to work on behalf of the people there." Fire and smoke are

2 https://rodericksteel.wixsite.com/reinos 
the most virtual of all material forms and mimic scientific principals. For Emanoel DeLanda, modern physics thinks in terms of unobservable forces, which he calls "attractors", that come together in complex ways to produce vectors and form particular shapes or figures. The embodied "indian spirit" performs a metaphorical unleashing of these attractors, by a variety of means which in turn virtually and physically modify objects and bodies. For DeLanda, attractors modify matter and make it detecable. In real science, gasses, solids and liquids are different states of a single system, and the fire manipulated and smoke blown by the caboclo from a cigar or inverted pipe attract by modifying, awakening, activating - virtually and in the spirit world - the latent potential of ritual objects. Visitors close their eyes as the smoke is blown over them: they become haptic, rather than optic, in a reversal of touch's subordination to the visual. Smoke is perceived by the body, proprioceptively, through mechanosensory neurons in the muscles. Brian Massumi describes a knock-on effect of a ritual, caused by the heightening of energies "sustained long enough to leave a kind of afterimage of its dynamism that can be reactivated or injected into other activities (Massumi 1987, XIV)." The ritual weaves together intensive states and then directs connecting routes to a specific end, or cure. Though visitors might only eventually get "initiated", their bodies are graphically paired with "cosmic" lines on the ground. Each caboclo's signature ponto-riscado merges with the visitor's body, who then becomes a co-performer free to infuse symbols with subjective meaning. Roger Bastide, a French ethnographer who charted candomblé in the 50s, assigned pontos riscados the task of "revealing individuals their secret life." (Bastide 2011, 95).

Victor Turner tells us that ambiguity reigns on the borders of ritual frameworks and that liminality is not a concept that explains things (Turner 1988, 102). In the second volume of Capitalism and Schizophrenia, Deleuze and Guattari set out to write and create a number of "plateaus of intensity" in order to seek new vocabularies for overcoming Gregory Bateson's formulation of the plateau, from his essay on Balinese culture (Deleuze \& Guattari 1987, 24). They take on directly his understanding of plateaus as "a continuous self-vibrating region of intensities whose development avoids any orientation toward a culmination point or external end" (Deleuze \& Guattari 1987, 24). This recalls Pai Nilson's description of the forcefield into which visitors are brought into by the cosmograms drawn during healing sessions: "It's a science and wisdom in which a person is trapped within positive energies that suppress the negative forces and dispel them. But there is a double current here: After this release the same symbols then bring goodness." The polisemic nature of these symbolic arrows, drawn on the ground in the healing sessions, is very different from the course they prescribe on airport runways. Within the ponto-riscado rituals such symbols become forcefields "in play": they eschew specificity and are emergent 
to visitor embodiment. Airport signs, however, are not "in play": there may be minor variations from country to country, but their meanings have remained fixed since the 1951 International Civil Aviation Convention. The ponto riscado, on the other hand, is a 'self-vibrating region': a connected set of moments and experiences which are nonetheless able to move themselves. If indeed it is the territorialization into region that holds the plateau together then the umbanda temple provides a highly symbolic region, potentialized through these "vibrations". Graphic lines and symbols paradoxically give the plateau, as a field of potential virtual energies, a mobile ground. Indeed the word "vibration" figures as one of Umbanda's main "scientific principles". A quick search on the internet reveals a series of texts based on the "Kybalion", published in 1908, that herald umbanda's link to science and "hermetic principles" championed thousands of years ago by ancient Egypt's Masters, in which the "differences between various manifestations of Matter, Energy, Mind and Spirit, result from the variable vibrational orders", and which allows the Hermetic student "to know his mental vibrations, as well as also that of others."

Perhaps it is from the fact that the onus of interpretation during healing rituals befalls the visitor, who is unable to effectively modify the ritual structure, that the ponto-riscado generates a cure. "The plateau of intensity is a goal-in-itself, a situation of constant evolution and becoming in which conflict does not build, but is expressed and released." The only possible conflict here, is how to individuate an assemblage of symbols that have been assigned a potential or power to cure within a mystical "science" that transcends the organized perceptual apparatus of subjectivity. Pai Nilson makes this relationship explicit: "A six-pointed star is made up of two triangles which balances the earth and the sky. The arrows, and other symbols could be perceived as being Indigenous signs but no, they are means of directing energies. Which is part of another wisdom which are other forms of consciousness acting on the astral body of the Indian spirits I receive, such as "Seven-Arrowed Indian".

As argued by Turner, events and performances are not simply structured, but have their own life. We have to study such moments as real instances of contingency, moments where meaning-formation and symbolism condense and take new forms. Nilson emphasizes: "The symbols address each visitor's universe". Symbols are individuated, and those who have been healed - some of whom later become initiated and receive their own caboclos - re-assign meaning to the symbols that have cured them. Once again, we turn to Campbell who specifies the functioning of a three-tiered symbolic system: physical conscience in a state of wakefulness; the spiritual, the dream; the inexpressible, and the absolutely unknowable." (Campbell 1997, 199). Campbell states that the term "meaning" can only refer to the first two, which belong to the sphere of science 
and signs. The inexpressible, the absolutely unknowable, can only be felt and no more today in the religious sanctuary than anywhere else. Campbell's "inexpressible" is reminiscent of greatness beyond all possibility of mathematical calcuation inherent to Kant's sublime. For Pai Nilson, this boundlessness is found in the distance between extremes summoned by the ponto-riscados hybrid forms, that connect with both African and western forms of thinking. In his own words: "Polarity exists in most traditional religions. Positive and negative co-exist: Masonry has its two columns. Card-readers, Tarot readers see everything in terms of polarity. The way a card falls is either positive or negative." DeLanda takes an example from thermodynamics, to describe a similar process: morphogenesis. For him, systems that embody a difference in intensity are adept at creating a phenomenon of experience. This happens, for example when polar opposites, such as cold air and hot air are separated in containers, and then mixed, producing a spontaneous flow of air from one side to the other. For him, "many phenomena, in geology, meteorology, biology and even economics and sociology, emerge spontaneously from the interplay of intensity differences." (Delanda 1997, 3). Indian spirits seemingly perform and manage morphogenetic intensities and energies, and fold deterministic causes in on themselves. This reverses what DeLanda calls physics' obessions with the final equilibrium forms in favor of a symbolically and magically constructed "difference-driven morphogenetic process which gives rise to those forms." (Delanda 1997, 4). The Ponto-riscado, and rituals in general, "free intensive differences from the extensive structures (structures extended in space-time) they give rise to". What matters here is the co-creation of phenomena of experience, which generate, in Deleuzian terms, important philosophical (and psychological) insights for the visitor that during the process of morphogenesis "before the final form is actualized, before the difference disappears." The ponto-riscado ritual orchestrates the interplay between these intensity differences, and gives rise to phenomena of experience in order to produce a phenomenon (a magical cure) that may also eventually produce scientific evidence (such as alterations in a medical exam). We are approximating, in such a case, Deleuze's notion of the body without organs, and his "spiritual automaton" that requires an inventive upsurge of affects and actions to respond to a novel sensory condition, that combines "transmit[s] the spiritual sense of the world directly to the brain." (Ramey 2012, 11). The visitor's self-performed transcendence possibly lies somewhere between what is empirical, personal and individuated, and what is transcendental in terms of an impersonal and pre-individual ritual. This is a vectorial space rather than a metrical one. Indeed, a body placed in the middle of a cosmogram quickly becomes an overwhelmed sensorium, unable at times to even perceive clearly enough to activate the imagination. We turn again to Kant's sublime as expression of the transcendent found in nature and a multi-sensory drama that overwhelms 
the body. Such a conception designates a disconnect between experience and symbolic imagination.

\section{CONCLUSION}

Using a Deleuze-ian analogy, it's as if the ponto-riscado restores a sick body to its n-dimensions which reality has gradually subtracted. In contrast to this airport tarmac arrows, onto which have been deposited all sorts of tyre skidmarks and engine oil, now denote lacerated lines of contagion, viral transmission, pandemic lines of flight. The airport that was previously an impersonal crossroads of convergence now coordinates diverging worlds, to produce invisible lines of flight that have become scatological decentralizers of biopower. Just like the ponto-riscado, airports have proved that "Liminality is a world of contingency where events and ideas, and "reality" itself, can be pushed in different directions." (Thomassen 2012, 700).

\section{BIBLIOGRAPHIC REFERENCES}

Alards-Tomalin. 2014. Airport security measures and their influence on enplanement intentions. Air Transp. Manag. 37, 60-68.

Bastide, Roger. (1948-1949). Ensaio de Uma Estética Afro-Brasileira. In: Impressões do Brasil: Roger Bastide, Fraya Frehese e Samuel Titan Jr. (Org.). São Paulo: Imprensa Oficial do Estado de São Paulo, 2011.

Campbell, Joseph. 1997. O Voo do Pássaro Selvagem. Editora Rosa dos Tempos. Rio de Janeiro.

Delanda, Manuel. 1997. The Machinic Phylum, "TechnoMorphica".

Deleuze, Gilles e Felix Guattari. 1987. A Thousand Plateaus: Capitalism and Schizophrenia (trans. Brian Massumi). Minneapolis: University of Minnesota Press.

Eriksen, Thomas Hylland. 1992. In limbo: notes on the culture of airports, easa meeting in Prague.

Foucault, Michel. 2007. Security, Territory, Population: Lectures at the Collège de France 19771978 pp. 1-4; see notes on p. 24, notes 1-4.

Geertz, Clifford. 1972. Deep play: notes on the Balinese cockfight. Daedalus, 134 (4) Fall, 56-86.

Kapferer, Bruce 1986. "The ritual process and the problem of reflexivity in Sinhalese demon exorcism." In Rite, Drama, Festival, Spectacle, John MacAloon, ed., pp. 179-207. Ithaca: Cornell University Press.

Ramey, Joshua Ramey. 2012. The Hermetic Deleuze: Philosophy and Spiritual Ordeal. Duke University Press.

Rappaport, Roy A. 1999. Ritual and religion in the making of humanity. Cambridge, UK: Cambridge University Press.

Sakano, A. 2016. Airport security and screening satisfaction: A case study of U.S. Journal of Air Transport Management 55.

Shaw, Robert. 2015. Bringing Deleuze and Guattari down to earth through Gregory Bateson: plateaus, rhizomes and ecosophical subjectivity. Theory, Culture \& Society, 32(7-8), pp.151-171. 
Tambiah, S. J. 1981. A performative approach to ritual. Proc. Br. Acad. 65.

Thomassen, Bjørn. 2012. Notes towards an Anthropology of Political Revolutions. Comparative Studies in Society and History.

Thompson, Robert Farris. 1983. Flash of the Spirit: African and Afro- American Art and Philosophy. New York: Random House.

Turner, Victor. 1987. The Anthropology of Performance. New York: paj Publications. 


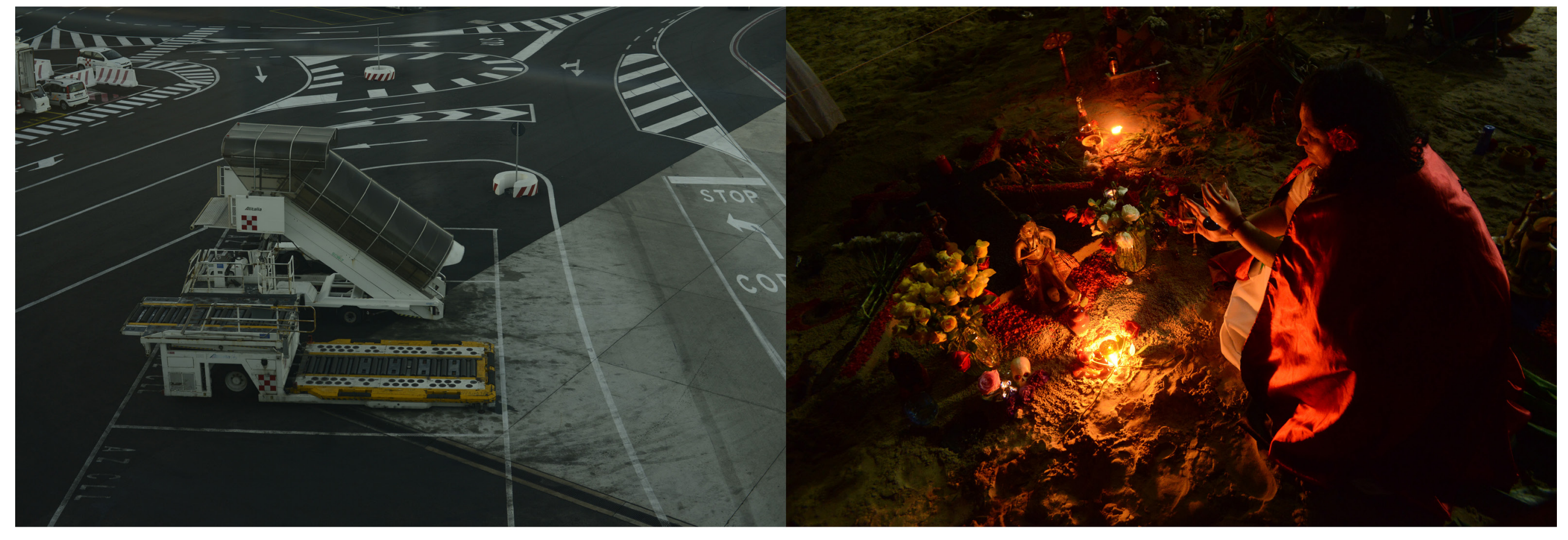




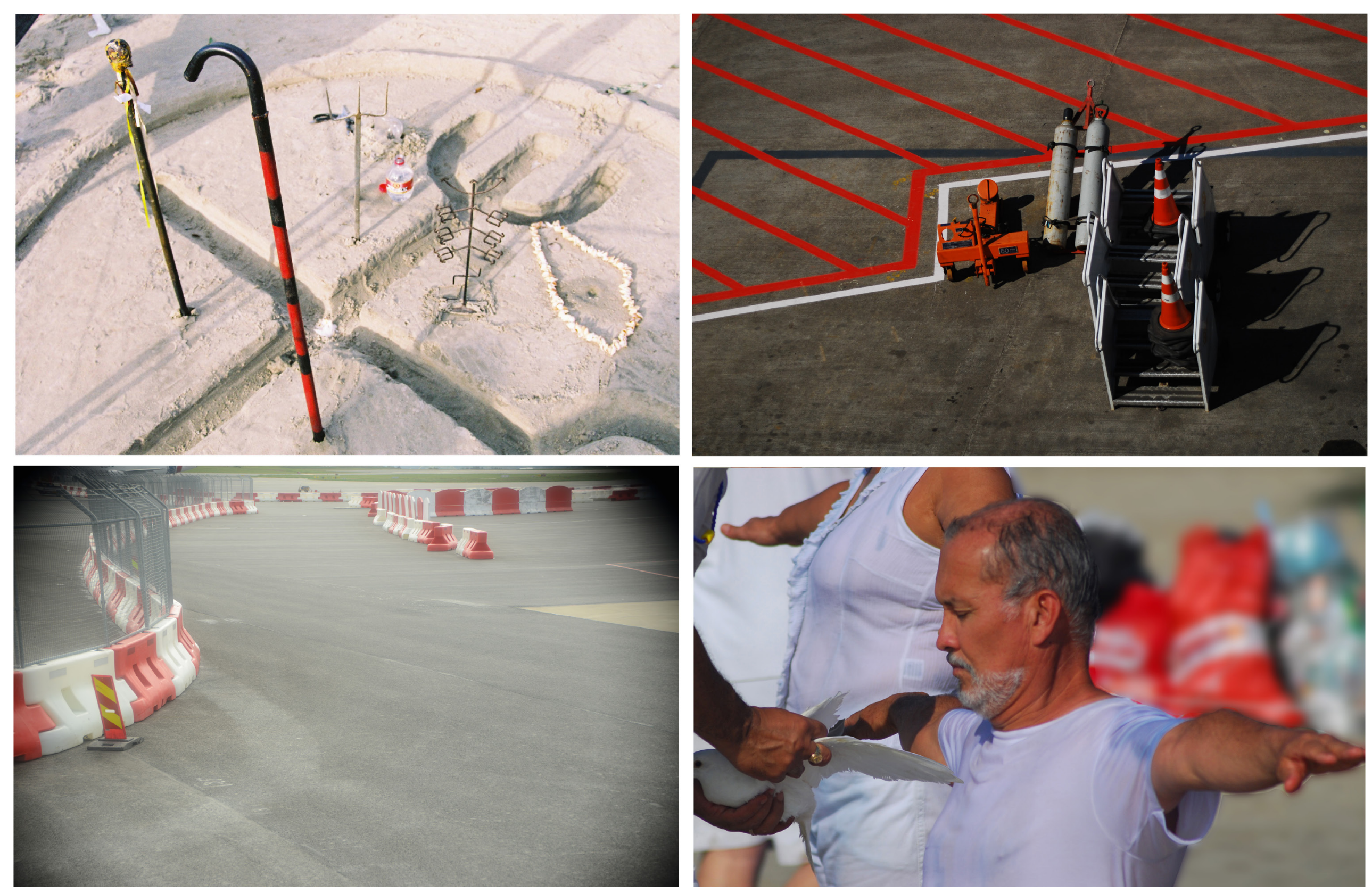




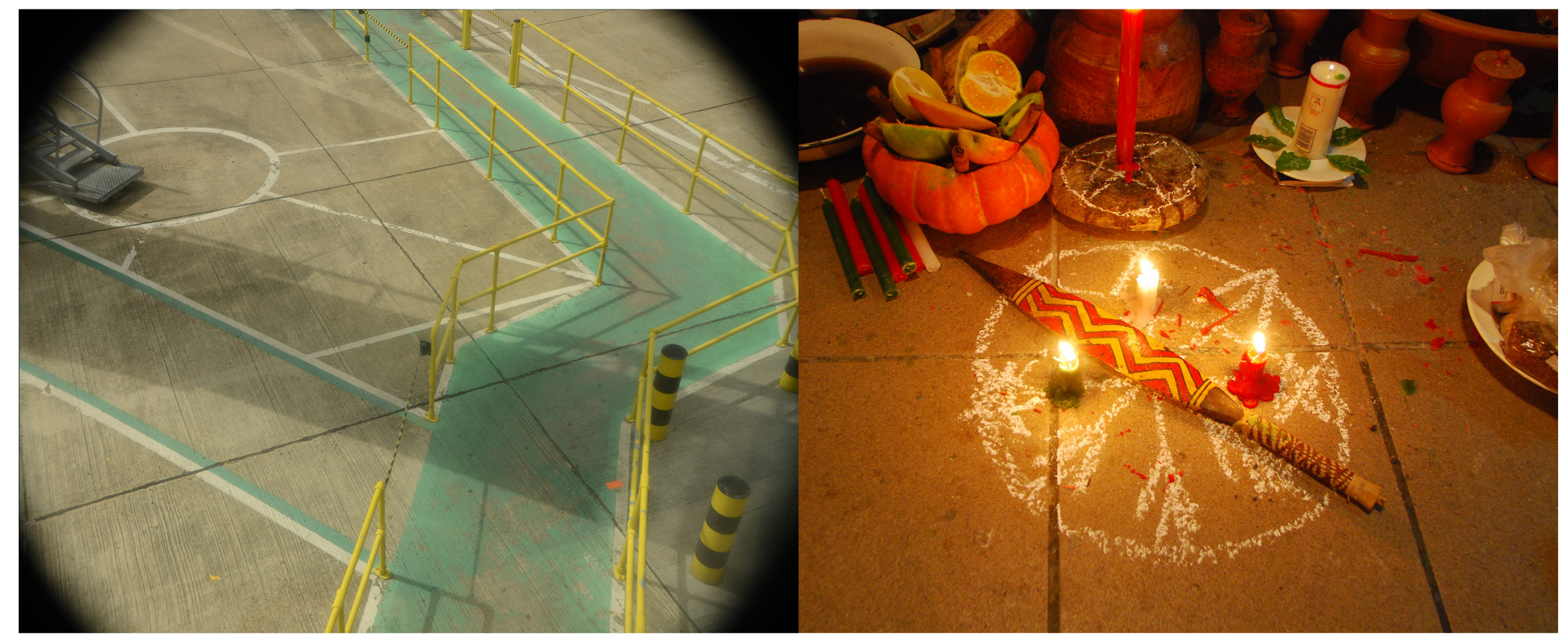



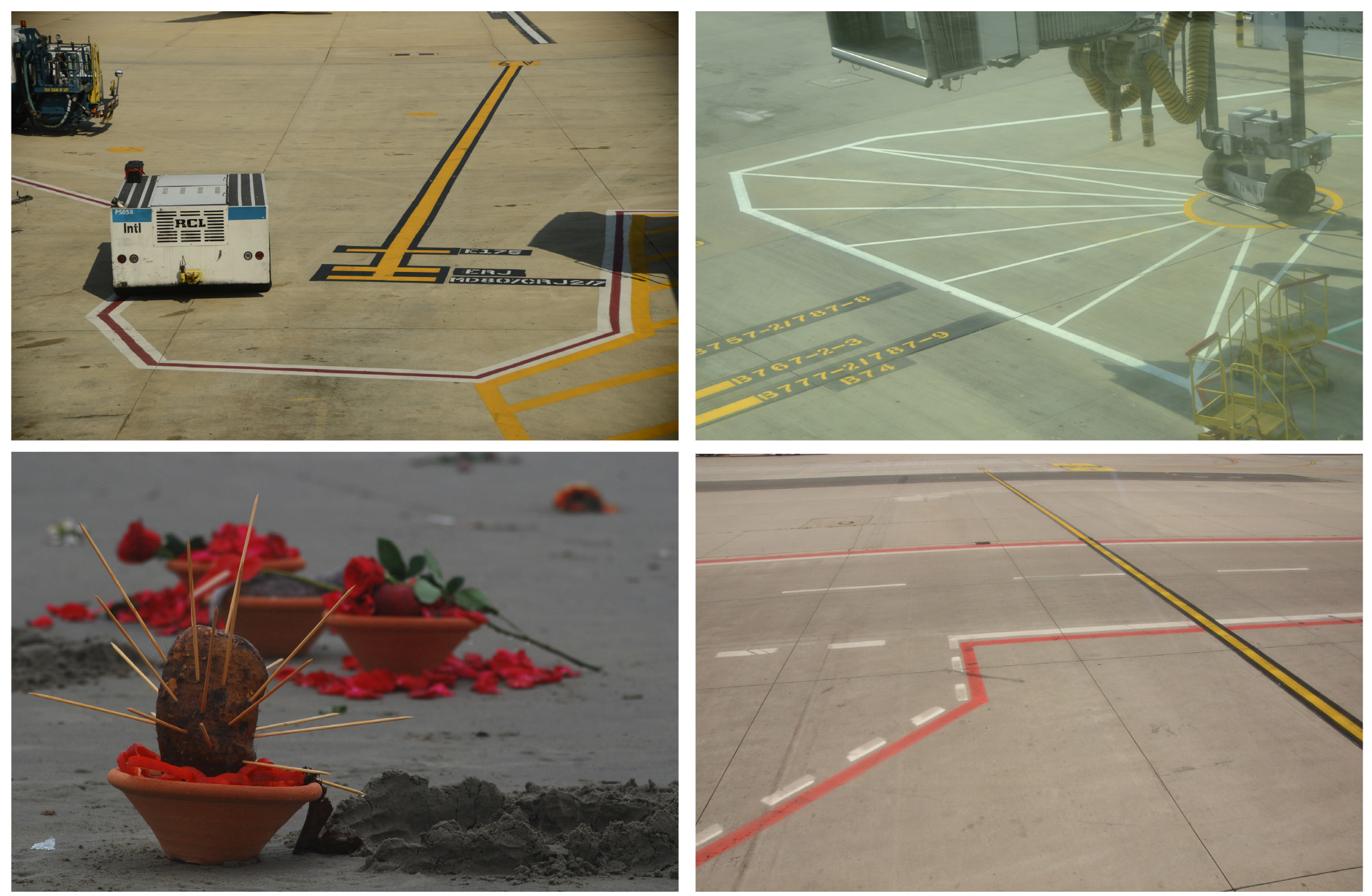

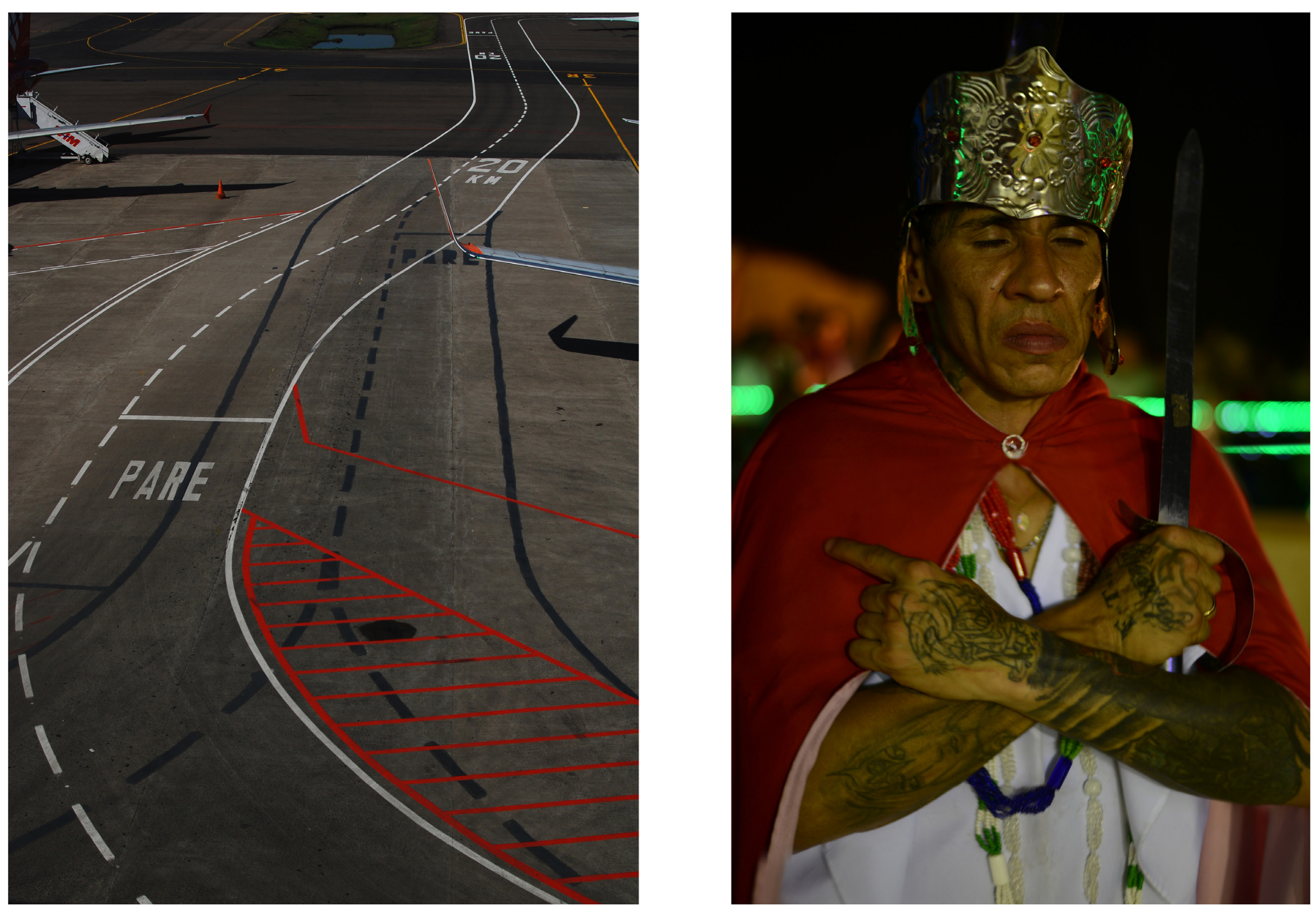

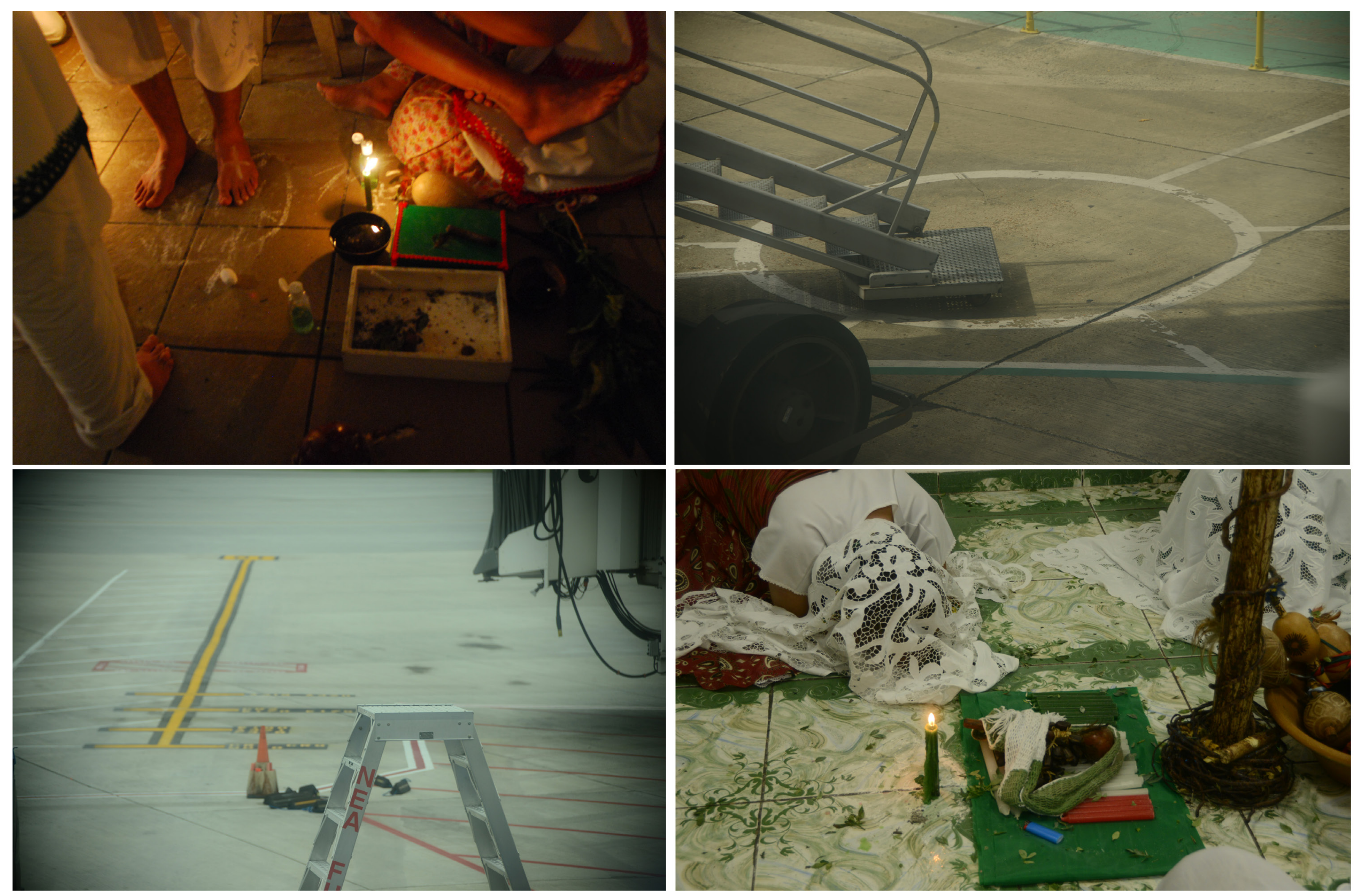

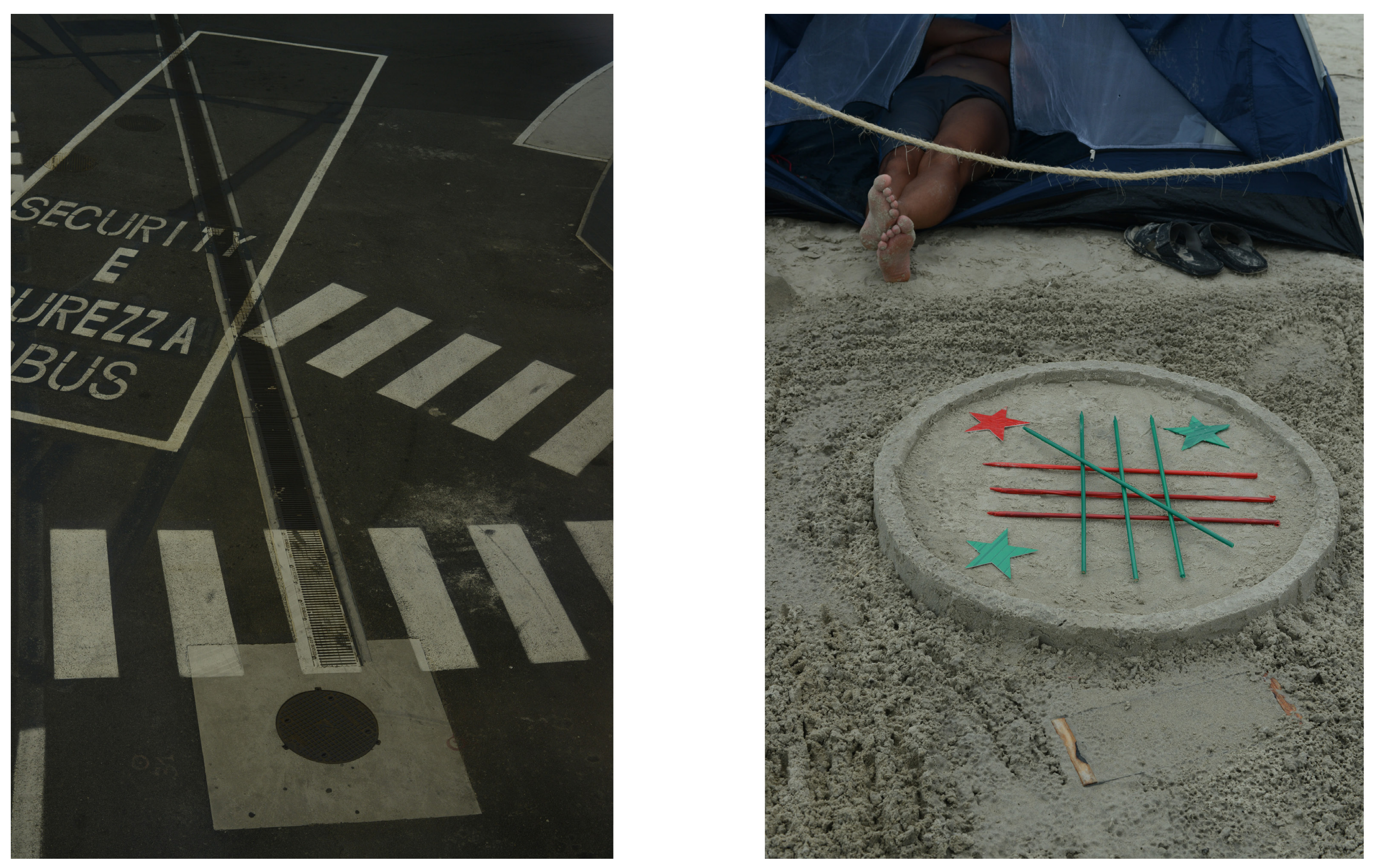


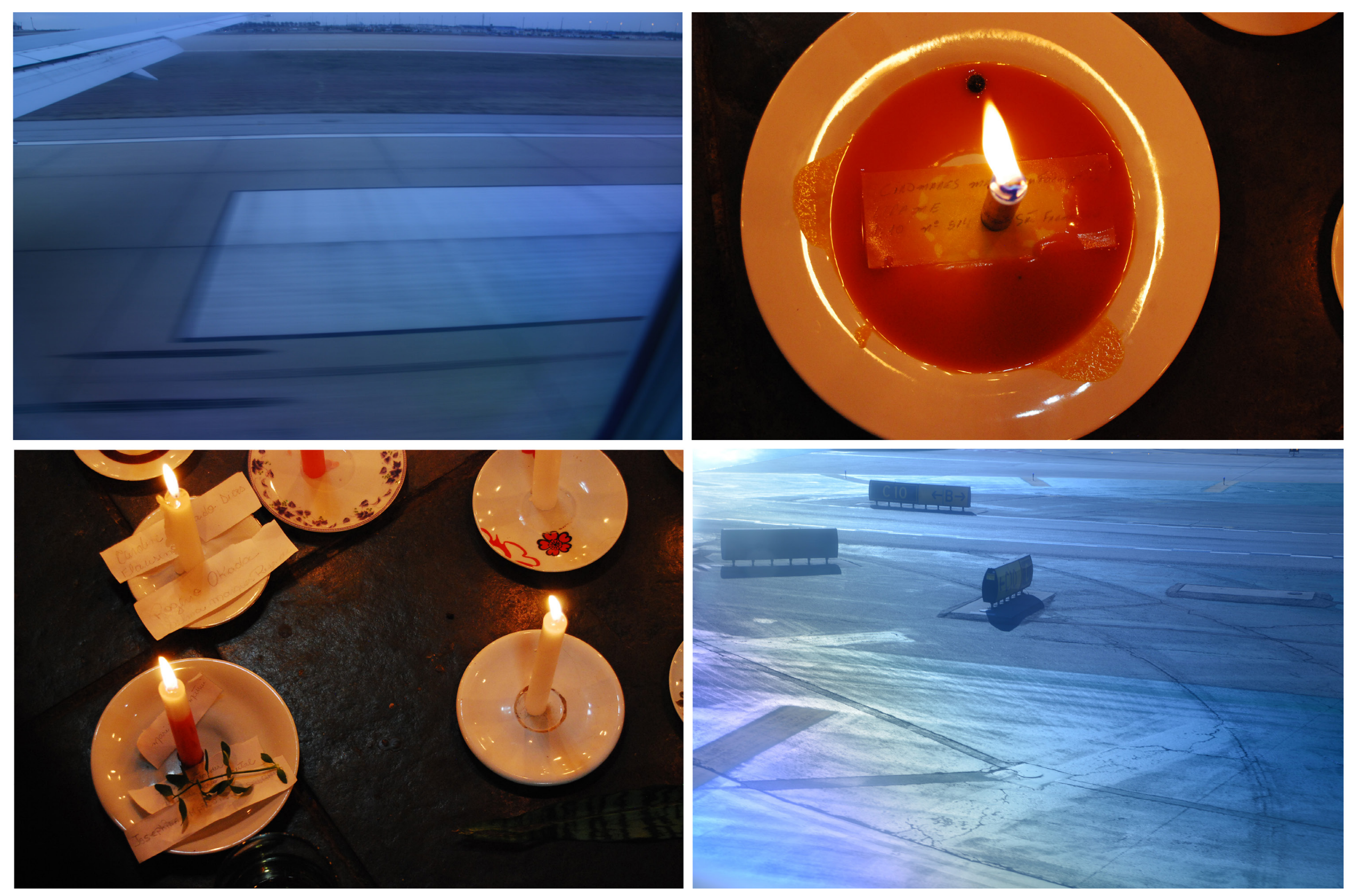




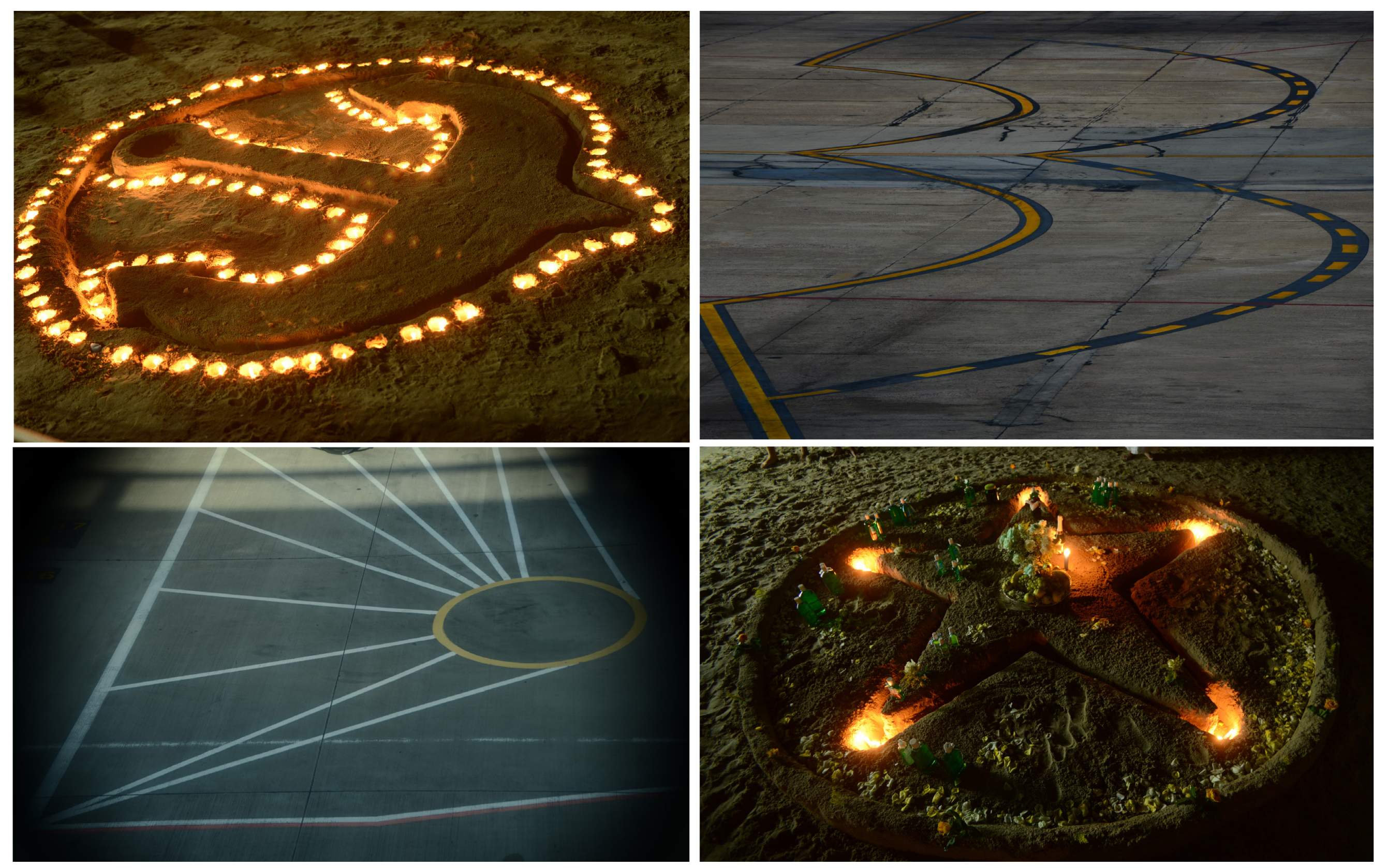




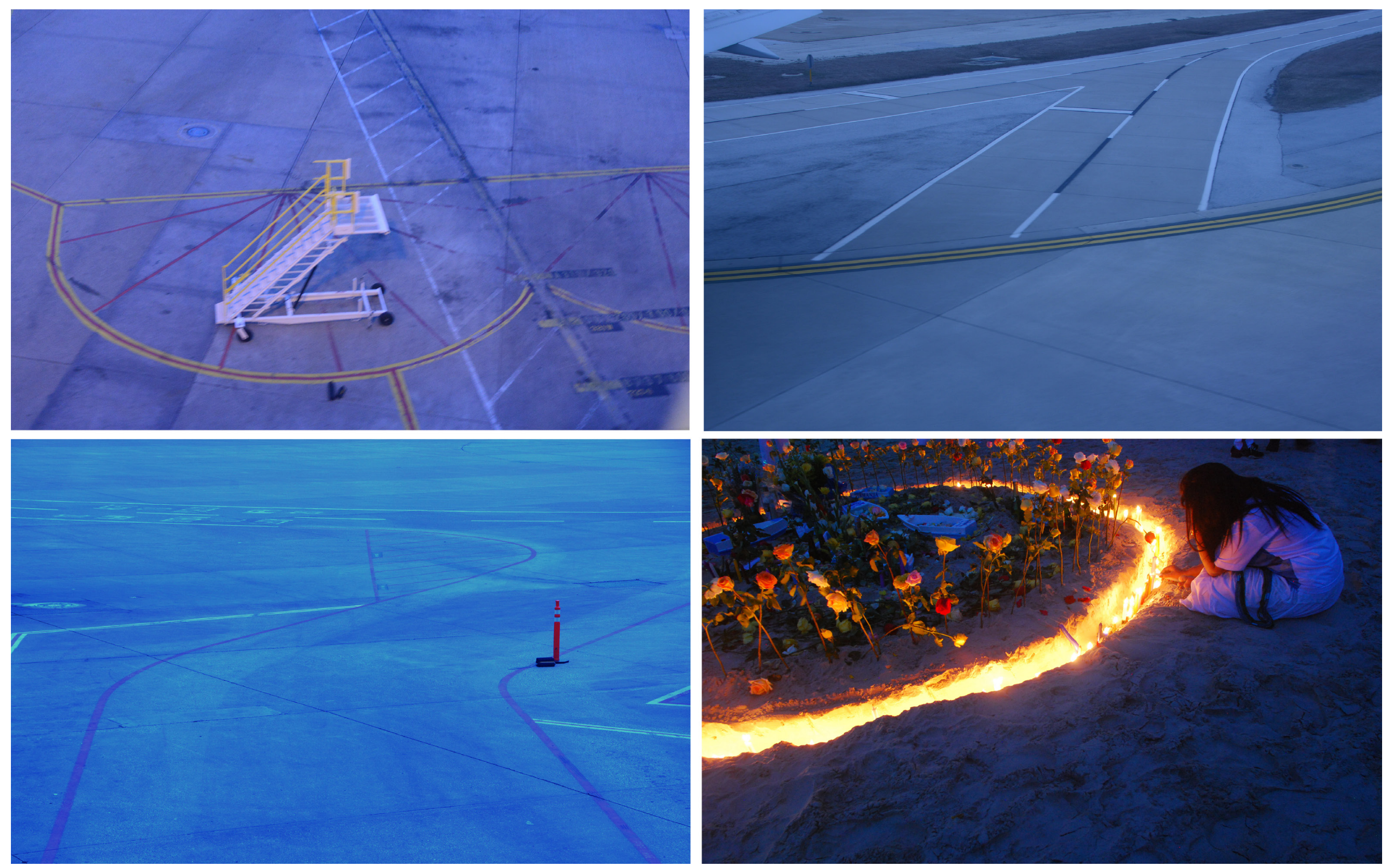




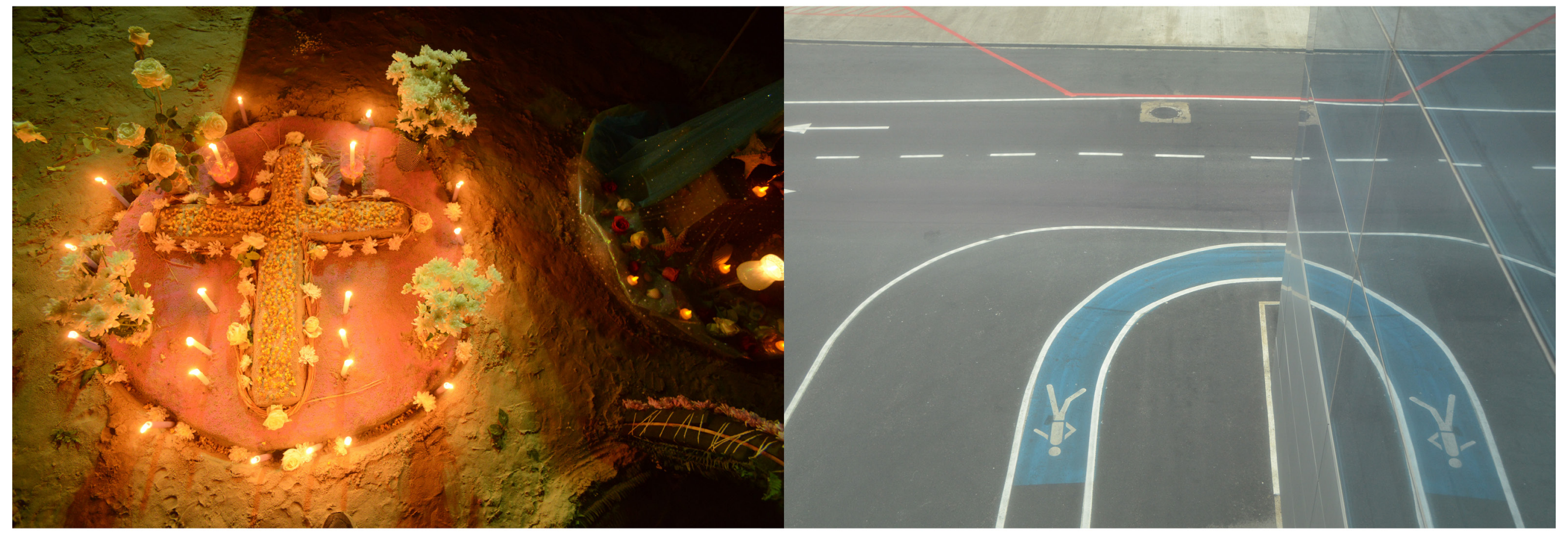



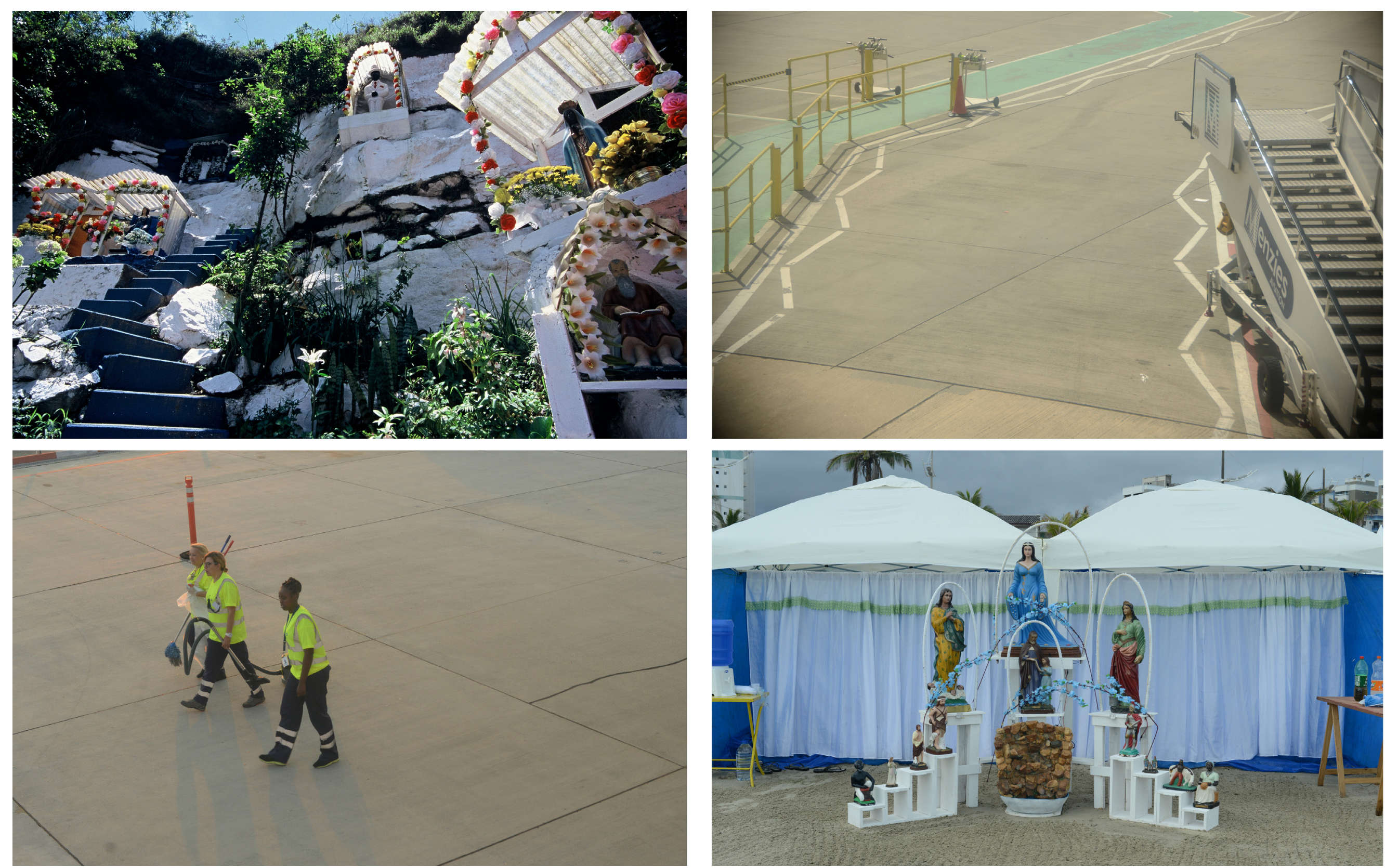


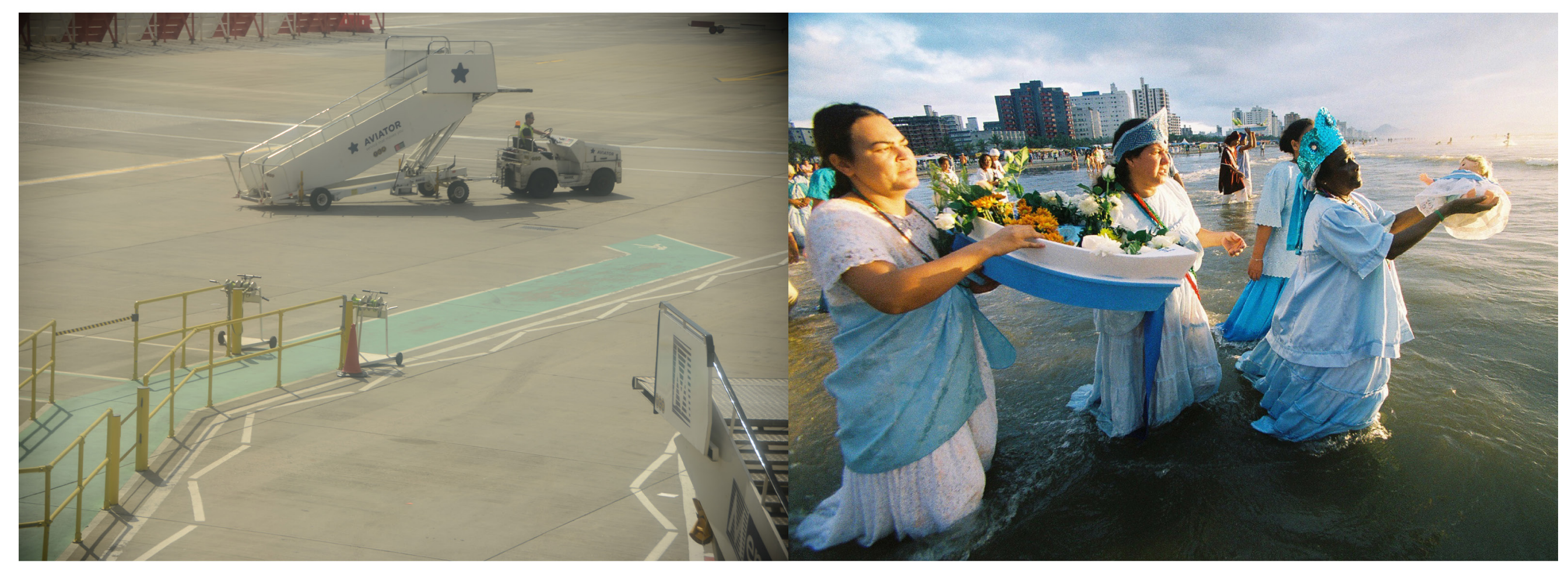


KEYWORDS:

Cosmogram;

polyptychs; umbanda; airport; photography.

\section{ABSTRACT}

This photographic essay creates an experimental parallel flow between ethnographic observation and polyptychal ${ }^{3}$ photographs, in order to align artistic and anthropological borders between African Brazilian cosmograms - pontos-riscados - and airport markings ${ }^{4}$. The polyptychs explore similarities between a 'visual vocabulary' prevalent in cosmograms and airport signs to create lines of flight between between these liminal spaces. Text and images suggest imagining new ways of relating diametrically opposed worlds: umbanda temple / airport; trance / being-in-transit; cosmogram/ airport markings; cure / covid-19. And to open up to multiple temporal dimensions that enable us to dislocate, to perceive anew through an artistic-academic manifestation.

Roderick Peter Steel is a PhD candidate and holds a Master's Degree in Audivisual Media and Processes from the Escola de Comunicações e Artes (ECA) at Universidade de São Paulo (USP). He holds a bachelor in Cinema from pela Boston University (1991). He has worked with documentaries in United States of America (WGBH-PBS) and England. He joins the research groups at USP: Poéticas no Audiovisual, and LabArteMídia. In his work, he starts with visual experiments to address issues related to different types of montage between body performance and audiovisual performance, within the territory of contemporary art and religions of African origin. E-mail: rodericksteel@gmail.com

Use license. This article is licensed under the Creative Commons CC-BY License. With this license you can share, adapt, create for any purpose as long as you assign the work

Received: 10/05/2020

Accepted: 11/03/2020

3 Beyond the obvious link between the polyptych with the ponto riscado, which is sometimes divided into four equal parts by its horizontal and vertical lines (that form a "Greek Cross") Polyptychs were most commonly created by early Renaissance painters for altarpieces in churches and cathedrals.

4 I started photographing the Iemanjá Party in Praia Grande in the 90s. Twenty years later, in a waiting room at the Tucson Airport, faded airplane tracks - recalling visual scores - recalled earlier encounters with umbanda's graphic moving lines. I revisited and separated photos of drawn signs - pontos riscados - taken on the beach, in some Umbanda, Tambor-de-Mina and Candomblé de Angola terreiros, and mixed them with photos of airport markings taken over a 5-year period. 